fournal of Medical Genetics (1972). 9, 457.

\title{
Apparent G-Monosomy, G-Deletion, and Incomplete Down's Syndrome in a Single Family
}

\author{
RINA SCHMIDT, GEORGE MUNDEL, MALKA ROSENBLATT, and \\ MARIASSA BAT-MIRIAM KATZNELSON
}

\begin{abstract}
From the Cytogenetic Laboratory and Pediatric Department ' $C$ ' Asaf Harofe Government Hospital, Zrifin and The Cytogenetic Institute, Department of Human Genetics, Tel-Hashomer Government Hospital, Tel-Aviv University Medical School, Israel
\end{abstract}

The clinical and cytogenetic entity of the Gdeletion syndrome was first described by Lejeune et al (1964). These authors described a retarded, hypertonic child with multiple malformations and characteristic facial features, hypertelorism, antimongoloid slants, micrognathia, and low set ears. The blood count revealed thrombocytopenia, eosinophilia, and an increase of the alkaline phosphatase in the granulocytes. Cytogenetic studies showed mosaicism of 2 cell lines, one with 45 chromosomes and monosomy $G$ and one with 46 chromosomes and a deleted $\mathrm{G}$ chromosome.

Since the phenotype of this child represented 'le contre type' of Down's syndrome, this new syndrome was called 'antimongolism'. Since the original report, 14 other cases with $\mathrm{G}$ group chromosome deletions or ring chromosomes were described (Broyer et al, 1966; Penrose, 1966; Reisman et al, 1966; Thorburn and Johnson, 1966; Al-Aish et al, 1967; Hoefnagel et al, 1967; Reisman et al, 1967; Weleber, Hecht, and Giblett, 1968; Bauchinger, Schmid, and Röttinger, 1968; Zdansky et al, 1969; Blank and Lorber, 1969; Challacombe and Taylor, 1969; Warren and Rimoin, 1970). Some patients displayed features similar to those reported by Lejeune and his colleagues but others were retarded children without the characteristic signs of antimongolism. Recently Warren and Rimoin (1970) divided the $G$ deletion syndromes into 2 different entities: the $G$ deletion syndrome I or antimongolism and the $G$ deletion syndrome II which comprises a variety of clinical disorders without the specific features of antimongolism.

In none of the reported cases were the parents or other sibs affected with a chromosomal aberration.

The purpose of this report is to describe a family whose 2 children displayed some features of Down's

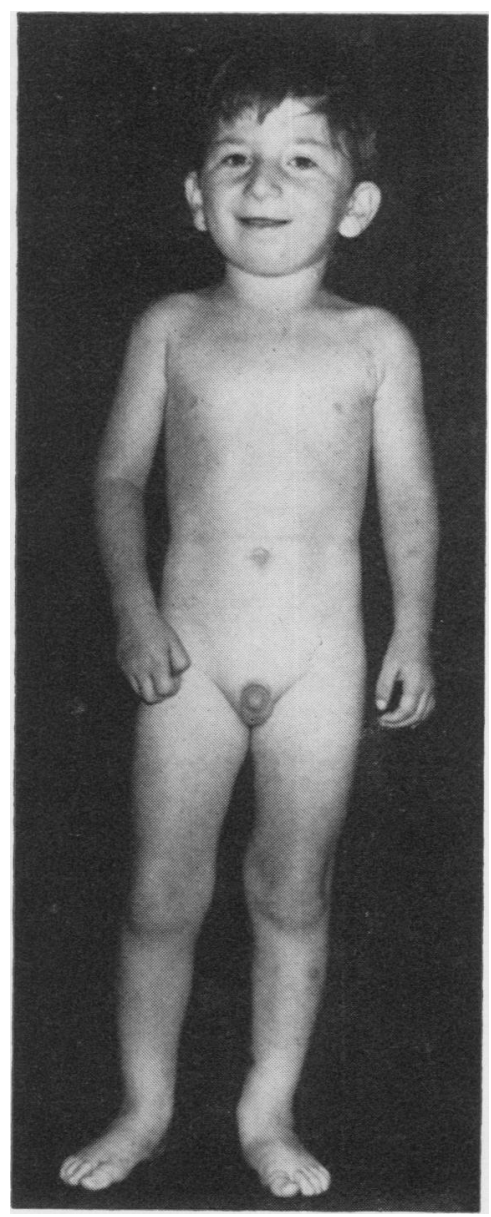

Fig. 1. Case 1 at 4 years. 
syndrome but had apparently normal karyotypes, a 3rd child was retarded and had a complete monosomy $G$, and the phenotypic normal mother had a deletion of the long arms of one of her G chromosomes.

\section{Case Histories}

Case 1. A boy born in 1966 to a 20 -year-old mother of Polish-Jewish origin and a 24-year-old father of Sephardic and Kurdish origin. Pregnancy and delivery were normal. Birthweight was $2420 \mathrm{~g}$. His psychomotor development was somewhat slow. He sat up at 10 months, walked at 16 months, and spoke words at 3 years. At the age of 3 years 8 months his IQ was estimated as 54 by the Terman-Merill (revised) intelligence test. His facial expression was somewhat peculiar with a prominent nose and large ears (Fig. 1) but no other abnormalities were found on the physical examination. Full blood counts and radiographs of the skull and skeleton were normal. The chromosome analysis from peripheral blood revealed in 2 cultures a complete monosomy $\mathrm{G}$ with a $45, \mathrm{XY}, \mathrm{G}-$ karyotype (Fig. 2); 40 cells were counted and analysed.

Case 2. A sister of case 1, born in 1968 after an uneventful pregnancy and by normal delivery. Birthweight was $2650 \mathrm{~g}$. The child had numerous signs of
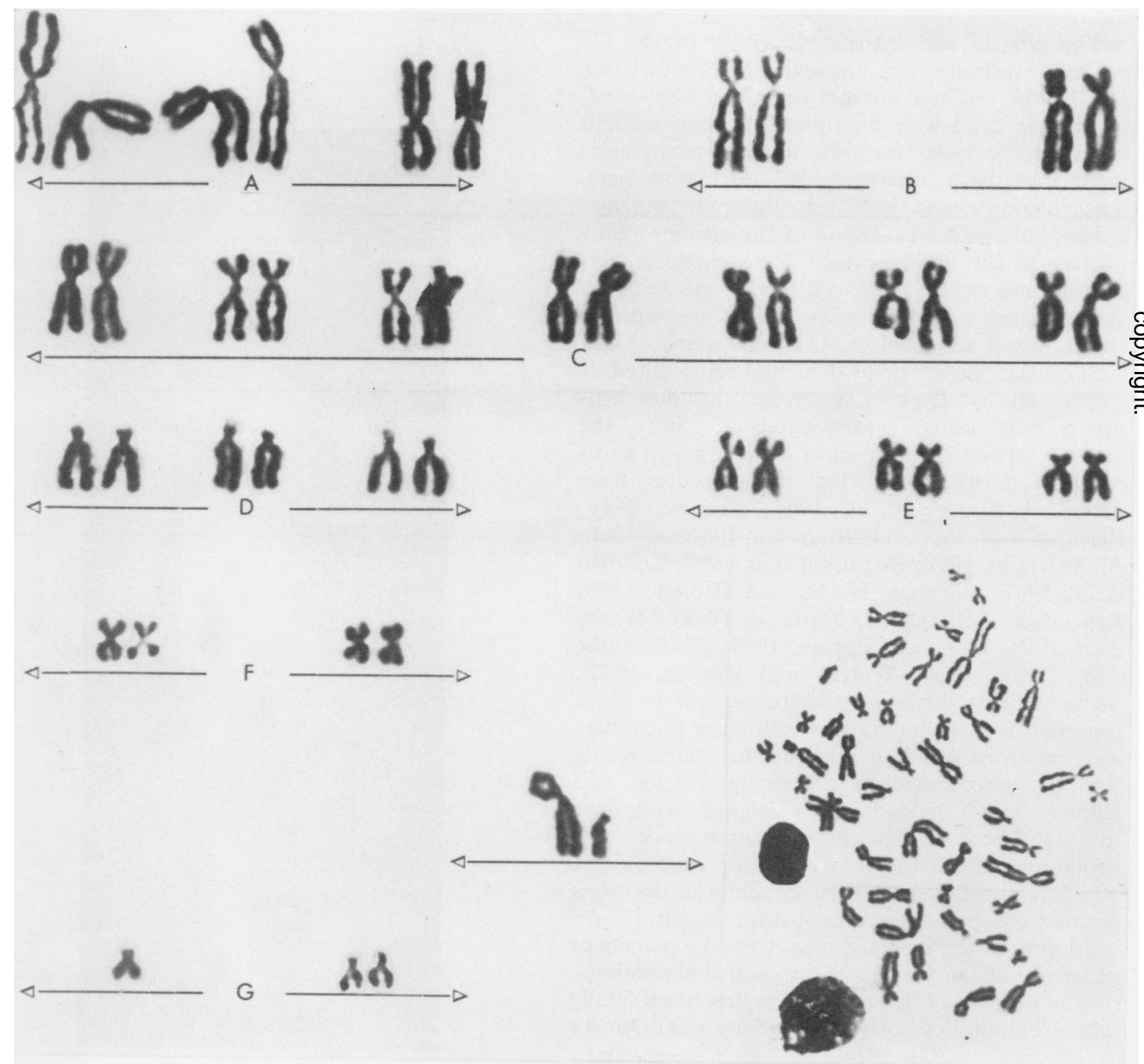

FIG. 2. Karyotype of case 1 showing complete monosomy $G(45, X Y, G-)$.
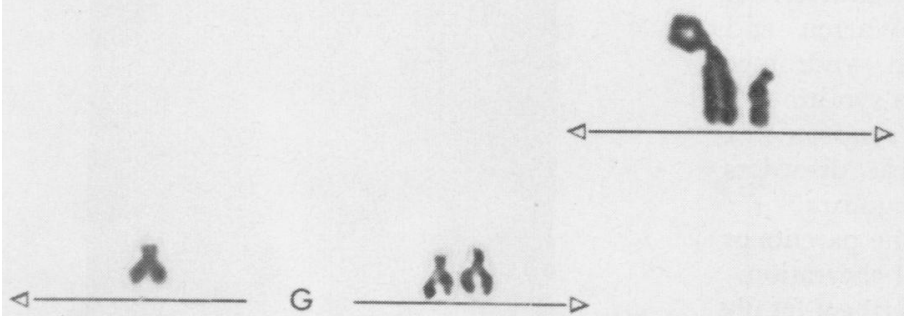
Down's syndrome: mongoloid slants, epicanthus, and congenital heart disease but no simian creases and her muscle tone appeared normal (Fig. 3). Dermatoglyphic analysis was equivocal but could be compatible with Down's syndrome (Table I). Chromosome analysis from peripheral blood revealed an apparently normal female karyotype, $46, \mathrm{XX}$. The child died at the age of 4 months of bronchopneumonia and heart failure. Necropsy revealed a trilocular-biventricular heart and bronchopneumonia.

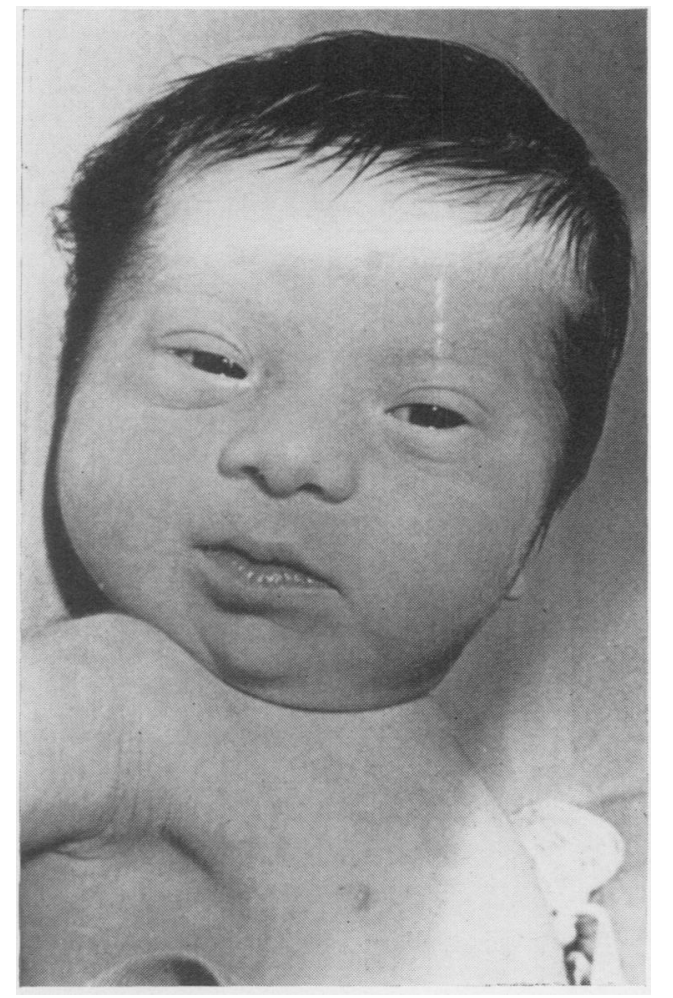

Fig. 3. Case 2 at 3 days. Note the epicanthal folds and mongoloid slants.
Case 3. A female, 3rd sib of cases 1 and 2, born in 1970. Her birthweight was $3020 \mathrm{~g}$. She too was born after an uneventful pregnancy and by normal delivery. Her facial features and dermatoglyphic and cytogenetic data were very similar to those of her sister (Fig. 4 and

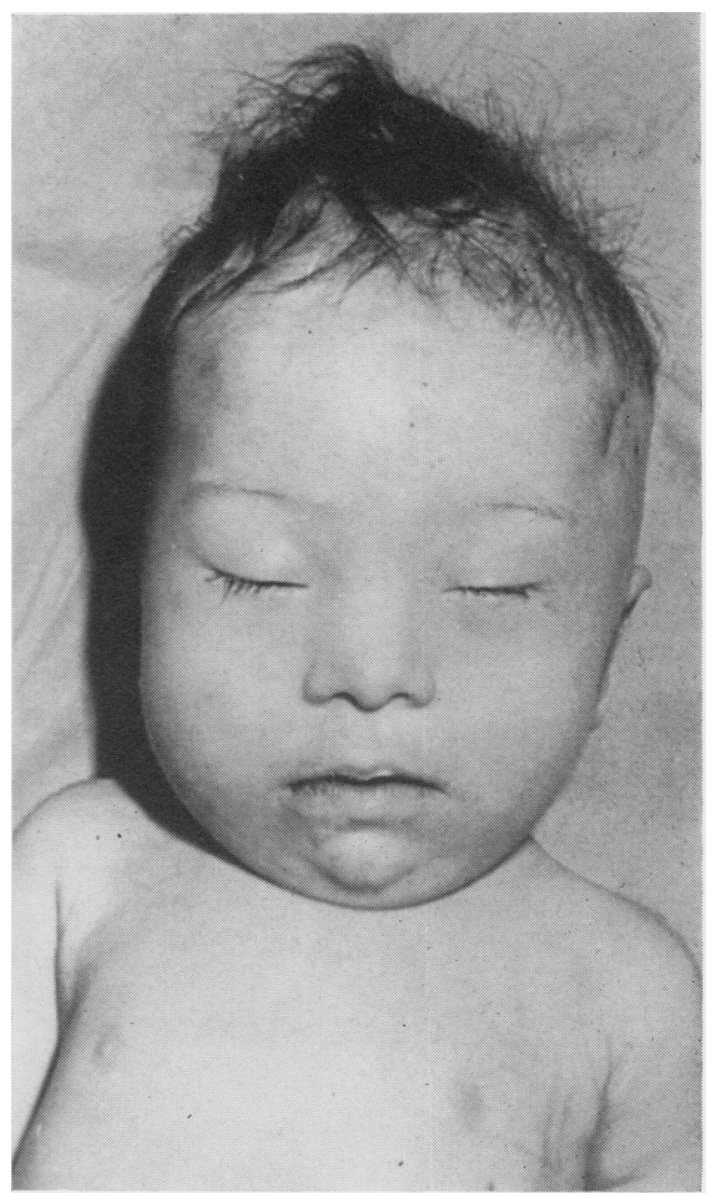

Fig. 4. Case 3 at 4 months.

TABLE I

DERMATOGLYPHS OF THE THREE CHILDREN AND THEIR PARENTS

\begin{tabular}{|c|c|c|c|c|c|c|c|c|c|c|}
\hline \multirow[t]{2}{*}{ Case } & \multirow[t]{2}{*}{ TRC } & \multirow[t]{2}{*}{$\begin{array}{l}\text { atd } \\
\text { Angle }\end{array}$} & \multicolumn{2}{|c|}{$\begin{array}{l}\text { Third } \\
\text { Inter- } \\
\text { digital } \\
\text { Pattern }\end{array}$} & \multirow[t]{2}{*}{$\begin{array}{l}\text { Main } \\
\text { Line } \\
\text { Index }\end{array}$} & \multicolumn{2}{|c|}{$\begin{array}{l}\text { Pattern } \\
\text { on } \\
\text { Hallucal } \\
\text { Area }\end{array}$} & \multicolumn{2}{|c|}{$\begin{array}{l}\text { No. of } \\
\text { Ridges* }\end{array}$} & \multirow[t]{2}{*}{$\begin{array}{l}\text { Norma Ford Walker } \\
\text { Index }\end{array}$} \\
\hline & & & L & $\mathbf{R}$ & & L & $\mathbf{R}$ & $\mathbf{L}$ & $\mathbf{R}$ & \\
\hline $\begin{array}{l}1 \\
2 \\
3 \\
4 \\
5\end{array}$ & $\begin{array}{l}90 \\
80 \\
93 \\
93 \\
63\end{array}$ & $\begin{array}{c}85^{\circ} \\
100^{\circ} \\
97^{\circ} \\
79 \cdot 5^{\circ} \\
79 \cdot 5^{\circ}\end{array}$ & $\begin{array}{l}+ \\
\pm \\
+ \\
+\end{array}$ & $\begin{array}{l} \pm \\
\pm \\
-\end{array}$ & $\begin{array}{l}5 \cdot 6 \\
11 \cdot 11 \\
12 \cdot 11 \\
10 \cdot 6 \\
10 \cdot 8\end{array}$ & $\begin{array}{l}\mathbf{L}^{\mathbf{d}} \\
\mathbf{L}^{\mathbf{d}} \\
\mathbf{L}^{\mathbf{d}} \\
\text { Not } \\
\text { Not }\end{array}$ & $\begin{array}{c}L^{d} \\
L^{d} \\
L^{d} \\
\text { ken } \\
\text { ken }\end{array}$ & $\begin{array}{r}20 \\
7 \\
12\end{array}$ & $\begin{array}{r}20 \\
5 \\
19\end{array}$ & $\begin{array}{l}-0.14 \\
+0.56\end{array}$ \\
\hline
\end{tabular}

* There is a familial tendency for a low total ridge count. The father's ridge count is the lowest due to 3 arches on his fingers. 


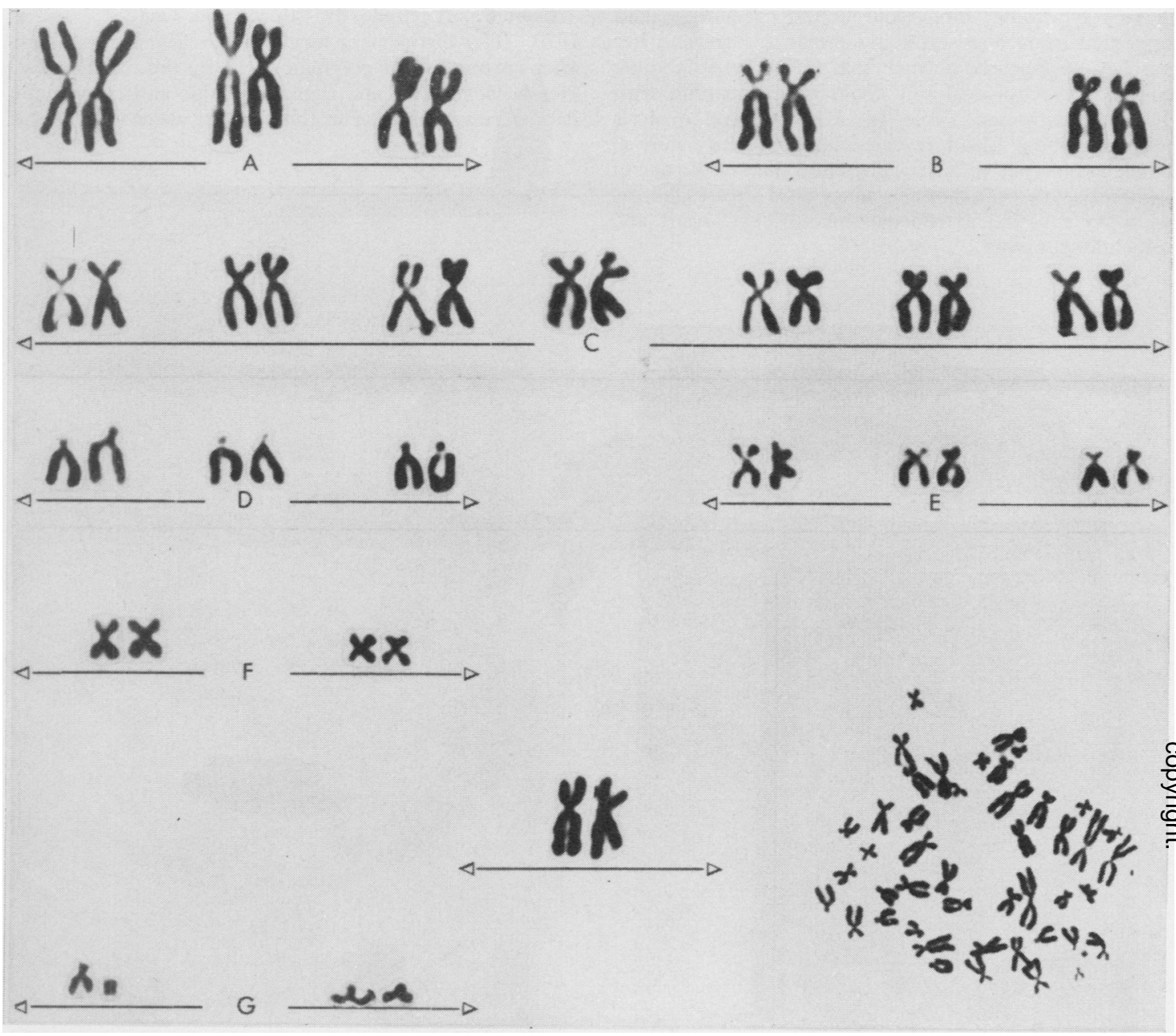

FIG. 5. Karyotype of case 4.

Table I). This child died at the age of 4 months of congenital heart disease. Necropsy revealed bronchopneumonia and a common atrio-ventricular canal.

Case 4. The mother of the 3 affected children is a healthy young woman. Chromosome analysis from peripheral blood showed a deletion of the long arms of one of the G-group chromosomes in all of the 30 analysed cells (Fig. 5).

Other Family Members. The maternal grandparents have normal karyotypes and normal dermatoglyphics. The father has a normal karyotype, 46,XY. His dermatoglyphs are summarized in Table I.

Autoradiographic Studies revealed that in case 1 one of the late replicating G-group chromosomes is missing while in case 4 the deleted chromosome belongs as well to the late replicating pair.

Fluorescence Studies with quinacrine unfortunately did not add any further information about the involved chromosomes.

\section{Discussion}

Our case 1 could be classified as belonging to the $G$ deletion syndrome II of Warren and Rimoin (1970). This retarded child who had a complete monosomy G-1, did not display the characteristic features of 'antimongolism', but resembled the child described by Al-Aish et al (1967) and the one described by Warren and Rimoin (1970).

It was always assumed that complete autosomal 
monosomy is lethal. The mother in the present family has a deletion of the long arms of one of her G-1 chromosomes $(46, \mathrm{XX}, \mathrm{Gq}-$ ) and since she is obviously normal, it must be postulated that the deleted segment has been translocated to another chromosome, probably one of the C-group (see Fig. 5). During meiosis the deleted G-group chromosome was lost, but the translocated segment on the C-group chromosome was most probably preserved, thus accounting for the survival of case 1 .

The dermatoglyphic patterns of cases 2 and 3 showed high main line indices which according to Cummins (1936) is one of the typical features of Down's syndrome. On the other hand, the main line index of case 1 is unusually low. The presence of small distal loops in the girls' hallucal areas is also suspicious of Down's syndrome. However, their Norma Ford Walker indices are very low with values in the intermediate area of $-2 \cdot 4$ to $+2 \cdot 4$ (Walker, 1957), which are ascribed to doubtful cases. However, using the dermatoglyphic nomogram (Reed et al, 1970) confirmed the diagnosis of Down's syndrome in cases 2 and 3.

The 2 deceased girls displayed many clinical signs of Down's syndrome. They had characteristic mongoloid facies and endocardial cushion defects of the heart which are frequently associated with Down's syndrome (Schaffer, 1966). Their karyotypes did not show the expected trisomy G-1 but there were irregularities in some chromosomes of the C-group. In light of the karyotypes of the mother and brother, it can be postulated that they inherited the translocated G-segment of the mother, and this extra chromosomal mass accounted for their mongoloid features. In order to prove this theory more accurate methods are needed than are at present available.

To our knowledge this is the first case of the Gdeletion syndrome which was inherited from one of the parents. The chromosomal analyses of the mother and the 2 girls and the clinical picture of these children who displayed many features of Down's syndrome, support the theory that complete autosomal monosomy is incompatible with life. Thus it might be assumed that the previously reported cases of complete G-monosomy were rather partial deletion syndromes with translocated segments which were not revealed by the available methods.

\section{Summary}

A retarded child with an apparently complete monosomy $G$ and his 2 sisters who displayed features of Down's syndrome but had 46,XX karyotypes are described. The phenotypic normal mother had a $46, \mathrm{XX}, \mathrm{Gq}-$ karyotype. It is assumed that the mother and all her children had a translocation chromosome, comprised of the deleted long arms of the G-group chromosome onto a Cgroup chromosome. The translocated G-group chromosomal mass accounts for the survival of the boy and the partial Down's syndrome of the girls.

REFERENCES

Al-Aish, M. S., De La Cruz, F., Goldsmith, L. A., Volpe, J., Mella, G., and Robinson, J. C. (1967). Autosomal monosomy in man. New England fournal of Medicine, 277, 777-784.

Bauchinger, M., Schmid, E., and Röttinger, E. (1968). Ein Fall mit einem Mosaik partielle Monosomie G/Monosomie G in den Lymphocyten des peripheren Blutes. Humangenetik, 6, 303-310.

Blank, C. E. and Lorber, J. (1969). A patient with 45,XX,G-/ 46,XX,Gr mosaicism. Fournal of Medical Genetics, 6, 220-223.

Broyer, M., Chevrie, J.-J., Aicardi, J., Vinh, L. T., and Thieffry, S. (1966). Malformations multiples chez un enfant porteur d'une monosomie partielle pour un chromosome 21-22. Presse Médicale, 74, 791-796.

Challacombe, D. N. and Taylor, A. (1969). Monosomy for a G autosome. Archives of Disease in Childhood, 44, 113-119.

Cummings, H. (1936). Dermatoglyphic stigmata in mongolian idiocy. Anatomical Record, 64, Suppl. 3, 11-14.

Hoefnagel, D., Schroeder, T. M., Benirschke, K., and Allen, F. H. (1967). A child with a group-G ring chromosome. Humangenetik, 4, 52-58.

Lejeune, J., Berger, R., Réthoré, M. O., Archambault, L., Jérôme, H., Thieffry, S., Aicardi, J., Broyer, M., Lafourcade, J., Cruveiller, J., and Turpin, R. (1964). Monosomie partielle pour un petit acrocentrique. Comptes Rendus Hebdomadaires des Séances de l'Academie des Sciences, 259, 4187-4190.

Penrose, L. S. (1966). Anti-mongolism. Lancet, 1, 497.

Reed, T. E., Borgaonkar, D. S., Conneally, P. M., Yu, P.-L., Nance, W. E., and Christian, J. C. (1970). Dermatoglyphic nomogram for the diagnosis of Down's syndrome. Fournal of Pediatrics, 77, 1024-1032.

Reisman, L. E., Kasahara, S., Chung, C. Y., Darnell, A., and Hall, B. (1966). Antimongolism. Studies in an infant with a partial monosomy of the 21 chromosome. Lancet, 1, 394-397.

Reisman, L. E., Darnell, A., Murphy, J. W., Hall, B., and Kasahara, S. (1967). A child with partial deletion of a G-group autosome. American fournal of Diseases of Children, 114, 336-339.

Schaffer, A. J. (1966). Diseases of the Newborn, 2nd edition, p. 250. W. B. Saunders Co., Philadelphia.

Thorburn, M. J. and Johnson, B. E. (1966). Apparent monosomy of a $\mathrm{G}$ autosome in a Jamaican infant. Fournal of Medical Genetics, 3, 290-292.

Walker, N. F. (1957). The use of dermal configurations in the diagnosis of mongolism. Fourna! of Pediatrics, 50, 19-26.

Warren, R. J. and Rimoin, D. L. (1970). The G deletion syndromes. fournal of Pediatrics, 77, 658-663.

Weleber, R. G., Hecht, F. and Giblett, E. R. (1968). Ring-G chromosome, a new G-deletion syndrome? American fournal of Diseases of Children, 115, 489-493.

Zdansky, R., Bühler, E. M., Vest, M., Bühler, U. K., and Stalder, G. (1969). Familliäres Mosaik mit G-Ring. Humangenetik, 7, 275-286. 